\title{
Effect of E-Word of Mouth through Instagrams on Purchasing Decisions in Twin House Coffee \& Kitchen Restaurant, Cipete, Jakarta Selatan
}

\author{
Dhiny Irena Sari ${ }^{1}$, Diena Mutiara Lemy ${ }^{2}$, Rahmat Ingkadijaya ${ }^{3}$ \\ 1,3 Sekolah Tinggi Pariwisata Trisakti \\ 2Sekolah Tinggi Pariwisata Pelita Harapan \\ 1Dbynasari23@gmail.com
}

\begin{abstract}
Social media is widely used for restaurant entrepreneurs to market their business due to its ease and low cost. One of such media is Instagram. This research is to determine the effect of Electronic Word of Mouth through Instagram in terms of Intensity dimensions, Valence of Opinion and Content and to find out whether E-Word of Mouth through Instagram has a joint influence on Purchasing Decisions at Twin House Coffee \& Kitchen Restaurant, Cipete, South Jakarta. Quantitative research with a descriptive approach is employed. The population covers the customers of the restaurant for 6 months, as many as 20,255. Slovin formula is used to determine the sample size of 100 respondents. Nonprobability sampling technique is carried out by convenience sampling technique. The results indicate that partially electronic word of mouth, namely the intensity dimension has a positive and significant influence on purchasing decisions, the valence variable of opinion does not have a positive and significant effect on purchasing decision variables. Content variables have a positive effect on purchasing decision variables. Simultaneously Intensity (X1), Valence Opinion (X2), and Content (X3) variables have a significant effect jointly on the purchasing decision variable (Y) at Twin house Coffee \& Kitchen, Cipete Restaurant in South Jakarta.
\end{abstract}

Keywords: Electronic Word of Mouth, Intensity, Valence of Opinion, Content, Instagram, Purchase Decisions 


\section{A. Introduction}

The rapid development of internet enables people to use it for personal and business purposes. Internet marketing activities facilitate the marketers to communicate with their customers beyond time and space. Restaurant entrepreneurs have long adopted social media due to its low cost; one of the such media is Instagram which was released in October 2010. According to the Jakarta Tourism and Culture Office, the growth of the restaurant business in the city of Jakarta continues to increase. This is supported by the tendency of Indonesian people who want to be practical and consumptive. Nielsen Consumer \& Media View in the third quarter of 2017 shows an increase in the average expenditure of Indonesian people by 4\% compared to 2013. As a result of the current public tendency, businesses in the food and beverage is growing rapidly as well.

Restaurants in Jakarta are currently trying to provide the best products and services to attract consumers. To do this, restaurant entrepreneurs must be able to provide qualified products and have a good marketing strategy, one of them is by utilizing the internet such as social media, e-word of mouth, product development, marketing mix in order to gain more customers. Twin House Coffee \& Kitchen Restaurant in Cipete, South Jakarta is such an example. Established in 2014, this restaurant provides several western and eastern foods and drinks. This Twin House restaurant has a positive reviews from consumers regarding the taste of food, competitive prices, and the service.

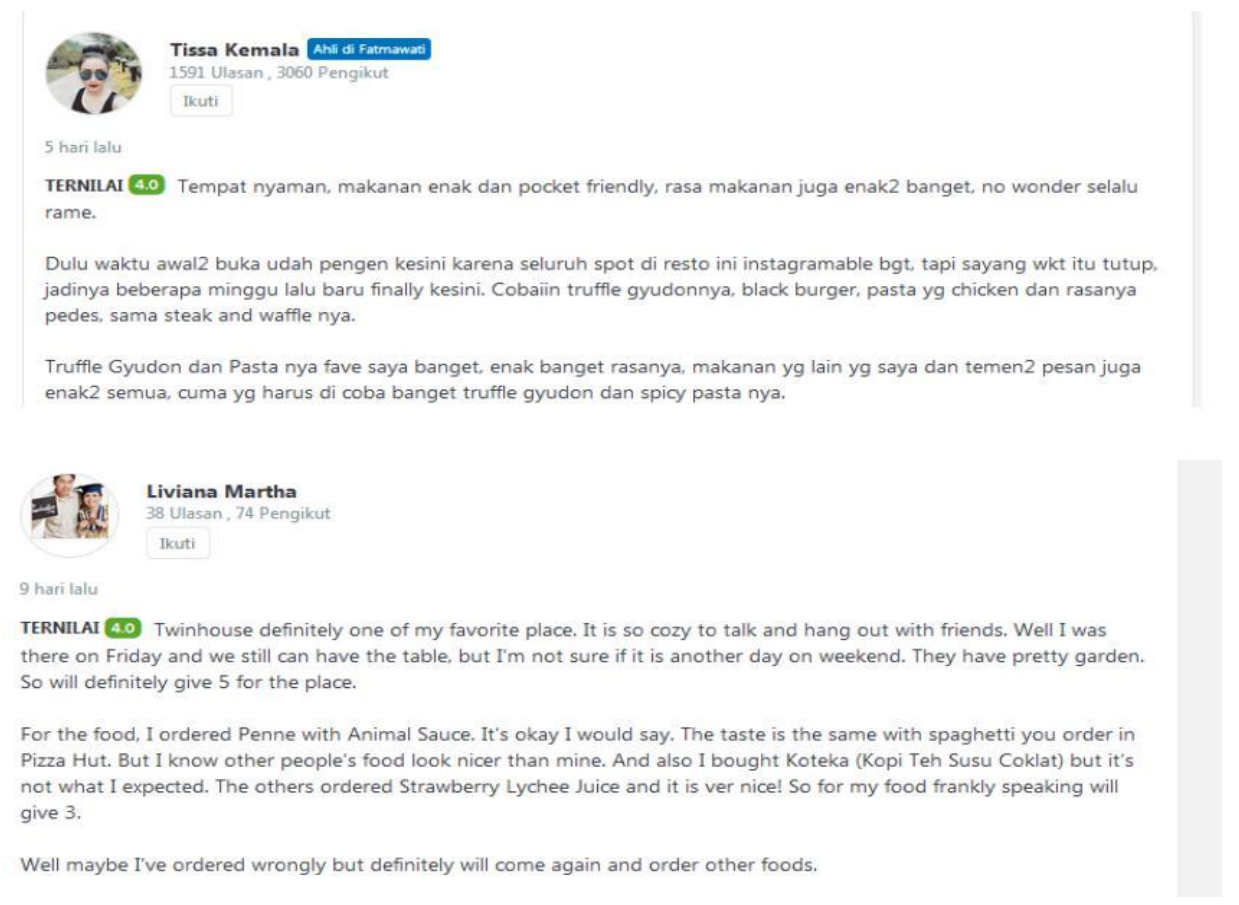

Figure 1 Review Costumer in Twin House Sumber: Zomato 2018 
To get new customers, Twin House restaurant employs social media such as Instagram to provide information and promotion, the other strategies is to use e-word of mouth as a promotional media such as Brochures, Openrice, etc.

Through the Instagram account (@twinhouse_cipete) this restaurant provides information on the latest innovations in food and beverages, coffee best sellers, as well as events and best photos for their Instagram account followers. This is an attraction in the restaurant promotion. If usually cafes or restaurants spread banners in other places, not like the Twin House. The promotions he uses through e-word of mouth and cooperation through food bloggers and concept and instagramable restaurant designs make many people interested to come to this restaurant.

In addition, related to previous research, Lerrthaitrakul \& Panjakajornsak (2014) stated that online e-word of mouth affects purchase decision making. This previous research also stated that the ease with which consumers read or find recommendations online had a strong impact on their purchasing decisions. Based on the background stated, it is necessary to do an analysis regarding "Effect Of E-Word Of Mouth Through Instagrams On Purchasing Decisions In Twin House Coffee \& Kitchen Restaurant, Cipete Jakarta Selatan".

\section{Formulation of Research Problems}

The research aims to investigate the following problems:

1. Is there an influence of Electronic Word of Mouth through Instagram in terms of dimensions of intensity to purchasing decisions?

2. Is there an influence of Electronic Word of Mouth through Instagram in terms of the dimensions of Valence of Opinion on purchasing decisions?

3. Is there an influence of Electronic Word of Mouth through Instagram in terms of the dimensions of content to purchasing decisions?

4. Does E-Word of Mouth through Instagram affect the purchasing decision at Twin House Coffee \& Kitchen restaurant, Cipete, South Jakarta?

\section{Research Objectives}

In line with the Research Problems, the objectives of this research are:

1. To find out the influence of Electronic Word of Mouth through Instagram in terms of dimensions of intensity to purchasing decisions.

2. To find out the effect of Electronic Word of Mouth through Instagram in terms of the dimensions of Valence of Opinion on purchasing decisions.

3. To find out the effect of Electronic Word of Mouth through Instagram in terms of the dimensions of content on purchasing decisions.

4. To find out whether E-Word of Mouth Through Instagram affects on purchasing decisions at Twin House Coffee \& Kitchen, Cipete, South Jakarta. 


\section{B. Literature Review}

\section{Marketing}

According to Kotler \& Amstrong (2012) Market is a collection of buyers and sellers who have transaction over a particular product of product class. The market also means as a group of buyers and sellers who make transactions of a particular product or product group (housing market or food ingredients). Kotler \& Amstrong (2012) also defines marketing as the society processes by which individuals and groups obtain what they need and want through creating, offering, and freely exchanging products and services of value with others. Marketing is the art of attracting and keeping profitable customers (Kotler and Keller in Natakusumah, Nursiana, Suryono, 2017). By using marketing strategy, the company will have an opportunity to attract customers and to keep them by using the tools of advertising, sales promotion, public relation, personal selling and direct marketing. Marketing is a social process in which individuals and groups get what they need and want by creating, offering and freely exchanging valuable products with others.

\section{Instagram as Social Media}

Instagram is an application of smartphones specifically for social media which is one of the digital media that has almost the same function as twitter, but the difference lies in taking photos in the form or place to share information with its users. Instagram can also inspire its users and can also increase creativity, because Instagram has features that can make photos more beautiful, more artistic and better (Atmoko, 2012: 10).

Welcome to Instagram, this is the opening sentence written by Kevin Systrom and Mike Krieger on his official blog on October 6, 2010, which marks the birth of the photo sharing revolutionary Instagram application. At the startup he founded, the company Burbn, inc. Kevin Systrom and Mike Krieger are working hard to realize photography-based social networking services in their dreams. Founding Steve Jobs (Apple), founder Bill Gates (Microsoft), founder Mark Zuckerberg (Facebook), founder Matt Mullenweg (Wordpress), Google and so on are world-class technology innovators who have developed revolutionary products from a young age (Atmoko, 2012: 10)

\section{Definition of E-WOM}

According to Chatterjee in Jalilvand and Samiei (2012: 2), increased use of the internet and social networks is also an important matter where currently Word of Mouth is not only done individually but can be in any form including the internet called Electronic Word of Mouth (e-WOM). The effectiveness of Electronic Word of Mouth is more effective than Word of Mouth communication in the offline world, because of greater accessibility and high range. 
Hennig-Thurau et al. (2004) said e-WOM is a statement made by actual, potential or consumer consumers before about a product or company where this information is available to people or institutions through internet media. Alexandrov, et., $\mathrm{Al}$ (2013) states that although it is similar to the WOM form, eWOM offers various ways to exchange information, many of which are anonymously or secretly. This is done to provide geographical and temporal freedom, especially e-WOM has at least some of them are permanent in the form of writing.

\section{E-WOM dimension}

Eunha Jeonga and Soo Cheong Jang's research in Goyette et al., (2010) which focuses on positive e-IWOM towards restaurants, describes that positive eWOM dimensions are reflected through the following dimensions:

a. Intensity

Defining intensity in e-WOM is the number of opinions written by consumers in a social networking site. Research conducted by Goyette et, al., (2010) divides the indicators of intensity as follows:

a. Frequency of accessing information from social networking sites

b. Frequency of interaction with users of social networking sites

c. The number of reviews written by users of social networking sites.

b. Valence of Opinion

It is the consumer's opinion, whether positive or negative regarding products, services and brands. Valence of Opinion has two characteristics namely negative and positive. Valence of Opinion includes:

a. Positive comments from users of social networking sites

b. Recommendations from users of social networking sites

c. Content

It is the content of information from social networking sites related to products and services. Indicators of content include:

a. Information on food and beverage variations

b. Information on quality (taste, texture and temperature) of food and drinks

c. Information about the prices offered.

\section{Definition of Purchasing Decisions}

To get an idea of the purchasing decision, the following definition will cover the terms. According to Kotler (2009) the buying decision is: "several stages carried out by consumers before making a purchasing decision for a product".

Purchasing decision making is a process of problem recognition, information seeking, evaluation and selection of product alternatives, selection 
of distribution channels and implementation of decisions on products to be used or purchased by consumers (Peter, 2009).

According to Setiadi (2010) purchasing behavior means that the activities of individuals are directly involved in the exchange of money with goods and services and in the decision-making process that determines the activity. The consumer's decision to buy a product always involves physical activity (in the form of direct consumer activity through the stages of the purchase decision making process) and mental activity (i.e when consumers assess the product according to certain criteria set by the individual).

\section{Dimensions of Purchasing Decisions}

According to Hasan (2014) the purchasing decision-making process takes place in harmony in five stages, but not all consumers go through all of these stages when they make a decision to buy, because in reality several stages can be passed depending on the type of purchase. The five stages are: problem recognition, finding information, alternative evaluations, purchasing decisions and after-purchase evaluations.

1. Problem recognition

Where the purchasing process starts when the buyer recognizes the problem or needs. These needs can arise due to external or internal stimuli.

2. Search for information

After recognizing the problem, consumers will seek information in advance about a product they need. Information retrieval can be done in various ways, namely by searching reading material, asking friends, doing online activities, and visiting the store to learn about the product.

3. Alternative evaluation

In this stage consumers realize their needs to be a desire for a particular product or brand. Consumers also evaluate a product as a set of attributes that have different benefits to meet their needs.

4. Purchasing Decisions

After evaluating, consumers can form the intention to buy the most preferred brand. The attractiveness that exists in the product will increase consumer purchase intention.

5. Post purchasing decision

If consumers are satisfied with the product purchased they will again buy the product. But on the contrary, if consumers are not satisfied they will not buy back the product. This can also trigger actions where consumers will or will not recommend the product to others. 


\section{Conceptual Framework}

From the results of the above theoretical basis, it can be described as the following research model.

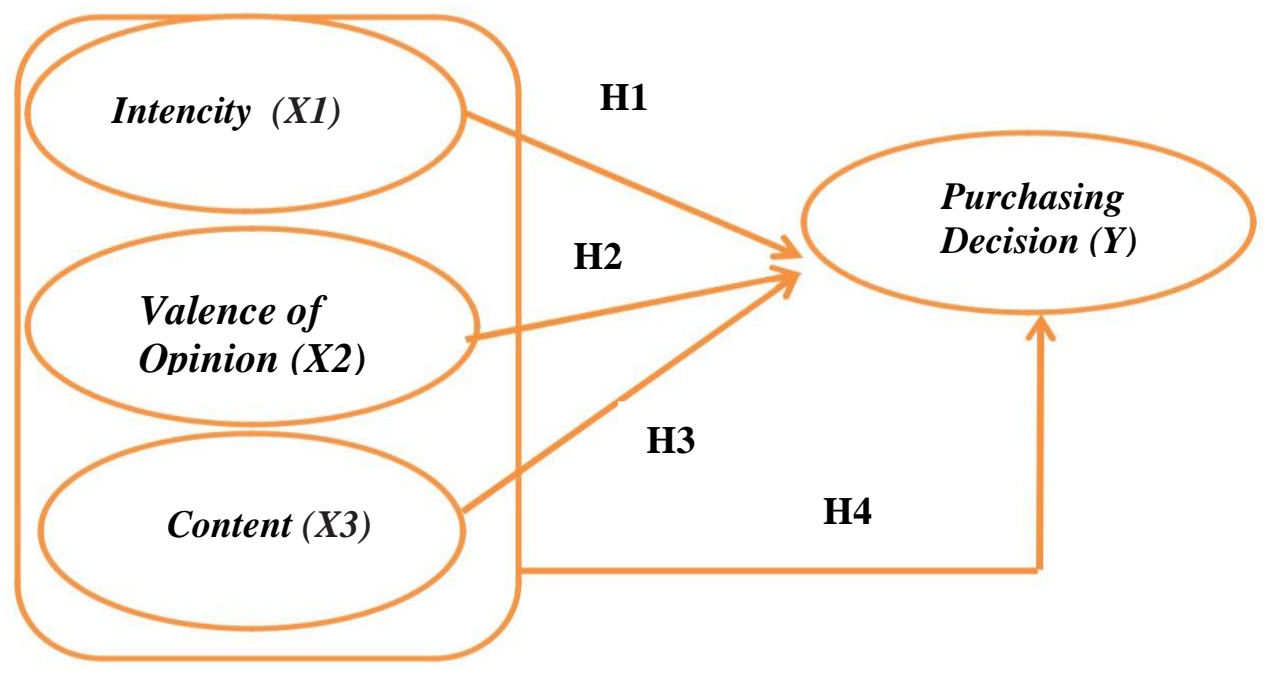

Figure 2 Conceptual Framework

\section{Hypothesis}

H1: Electronic Word of Mouth through Instagram in terms of intensity dimensions has a positive effect on purchasing decisions

H2: Electronic Word of Mouth through Instagram in terms of the dimensions of Valence of Opinion has a positive effect on purchasing decisions

H3: Electronic Word of Mouth through Instagram in terms of Content dimension has a positive effect on purchasing decisions

H4: E-Word of Mouth through Instagram together significantly influences the Purchasing Decision in Twin House Coffee \& Kitchen Restaurant, Cipete South Jakarta

\section{E. Research Methodology}

1. Research Types and Approaches

This research examines the validity of the hypothesis through data collection with survey methods. According to Sugiyono (2016: 6) the survey method is used to obtain data from certain natural places (not artificial), but the researchers treated them in collecting data for example by circulating questionnaires, tests, structured interviews and so on (treatment is not like in experiments).

\section{Population and Sample}

The population in this research is all customers at Twin House Coffee \& Kitchen for approximately 6 months, as many as 
20,255. Sugiyono (2016: 81) argues that the sample is part of the number and characteristics possessed by the population. If the population is large,

$\mathrm{n}=\frac{\mathrm{N}}{\mathrm{N}(\mathrm{e})^{2}+1}$

$\mathrm{n}=$ Sample Size

$\mathrm{N}=$ Total population

$\mathrm{e}=$ percentage of errors desired or tolerated with population and precision of $10 \%$

$\mathrm{n} \quad \underline{20,255}$

$=\underline{20,255}$

203,55

$\mathrm{n} \quad=99,508=100$

So the minimum number of samples studied is 100 respondents, to anticip ate invalidsample, a numer of 150 respondents are selected. Nonprobability sampling techniques were carried out by convenience sampling technique.

\section{Multiple Linear Regression}

The general regression formula is as follows:

$\hat{\mathrm{Y}}=\mathrm{a}+\mathrm{bX}$

The multiple linear regression formula is as follows:

\section{Information:}

$$
\hat{Y}=a+b 1 X 1+b 2 X 2+b 3 X 3
$$

dependent variable

$A=$ constant $/$ default / fixed value

$\mathrm{b} 1, \mathrm{~b} 2, \mathrm{~b} 3$ = independent variable regression coefficient

$\mathrm{X} 1 \mathrm{X} 2, \mathrm{~b} 3=$ independent variable

\section{Determination Coefficient Analysis \& Correlation Coefficient}

To assess the influence of variable $\mathrm{X}$ on $\mathrm{Y}$, the determination coefficient $(\mathrm{KD})$ is used which is the correlation coefficient which is usually expressed as a percentage (\%). According to Siregar (2016), the coefficient of determination is a number of numbers that states or is used to determine how much influence or contribution is given by one or more independent variables to the nonindependent variable $(\mathrm{Y})$.

Formula:

$\mathrm{KD}=(\mathrm{r})^{2} \times 100 \%$

Sources: (Siregar, 2014)

$\mathrm{KD}=$ Determinant coefficient value

$\mathrm{r} \quad=$ Correlation coefficient value 


\section{F. Discussion}

\section{Validity Test}

The technique used in the validity test is by using the Pearson Correlation technique. If a positive and significant Pearson Correlation value is obtained, the item is valid.

Table 1 Intensity (X1)

\begin{tabular}{clccc}
\hline No & Indikator & Rhitung & Rtabel & Keterangan \\
\hline 1 & indikator_1 & 0,529 & 0,197 & Valid \\
2 & indikator_2 & 0,582 & 0,179 & Valid \\
3 & indikator_3 & 0,551 & 0,179 & Valid \\
4 & indikator_4 & 0,549 & 0,179 & Valid \\
\hline
\end{tabular}

Sources: Primer Data 2018

Table 1 shows that all indicators used to measure the variables used in this study have a correlation value greater than 0.197 . From these results indicate that all indicators of intensity (X1) are valid.

Table 2 Valence of opinion (X2)

\begin{tabular}{clccc}
\hline No & Indikator & Rhitung & Rtabel & Keterangan \\
\hline 1 & indikator_1 & 0,395 & 0,197 & Valid \\
2 & indikator_2 & 0,367 & 0,197 & Valid \\
3 & indikator_3 & 0,499 & 0,197 & Valid \\
4 & indikator_4 & 0,511 & 0,197 & Valid \\
5 & indicator_5 & 0,384 & 0,197 & Valid \\
6 & indicator_6 & 0,490 & 0,197 & Valid \\
7 & indicator_7 & 0,439 & 0,197 & Valid \\
8 & indicator_8 & 0,231 & 0,197 & Valid \\
\hline
\end{tabular}

Table 2 shows that all indicators used to measure the variables used in this study have a correlation value greater than 0.197. From these results indicate that all indicators of Valence of opinion (X2) are valid.

Table 3 Content (X3)

\begin{tabular}{clccc}
\hline No & Indikator & Rhitung & Rtabel & Keterangan \\
\hline 1 & indikator_1 & 0,444 & 0,197 & Valid \\
2 & indikator_2 & 0,259 & 0,197 & Valid \\
3 & indikator_3 & 0,312 & 0,197 & Valid \\
4 & indikator_4 & 0,468 & 0,197 & Valid \\
5 & indicator_5 & 0,583 & 0,197 & Valid \\
6 & indicator_6 & 0,435 & 0,197 & Valid \\
7 & indicator_7 & 0,439 & 0,197 & Valid \\
8 & indicator_8 & 0,486 & 0,197 & Valid \\
\hline
\end{tabular}

Sources: Primer Data 2018 
Table 3 shows that all indicators used to measure the variables used in this study have a correlation value greater than 0.197. From these results indicate that all the indicator content (X3) is valid.

Table 4 Purchasing Decision $(\mathrm{Y})$

\begin{tabular}{rlccc}
\hline No & Indikator & Rhitung & Rtabel & Keterangan \\
\hline 1 & indikator_1 & 0,586 & 0,197 & Valid \\
2 & indikator_2 & 0,523 & 0,197 & Valid \\
3 & indikator_3 & 0,576 & 0,197 & Valid \\
4 & indikator_4 & 0,643 & 0,197 & Valid \\
5 & indicator_5 & 0,592 & 0,197 & Valid \\
6 & indicator_6 & 0,502 & 0,197 & Valid \\
7 & indicator_7 & 0,419 & 0,197 & Valid \\
8 & indicator_8 & 0,562 & 0,197 & Valid \\
9 & indicator_9 & 0,456 & 0,197 & Valid \\
10 & indicator_10 & 0,470 & 0,197 & Valid \\
\hline \multicolumn{5}{c}{ Sources: Primer Data 2018 }
\end{tabular}

Table 4 shows that all indicators used to measure the variables used in this study have a correlation value greater than 0.197 . From these results indicate that all purchasing decision indicators $(\mathrm{Y})$ are valid.

\section{Reliability Test}

Reliability testing in this study is to use the Cronbach Alpha formula. The reliability test results for each variable are summarized in the following table.

Table 5 Reliability Test

\begin{tabular}{ccl}
\hline Variabel & Alpha & Remark \\
\hline Intensity (X1) & 0,756 & Reliable \\
Valence of opinion (X2) & 0,723 & Reliable \\
Content (X3) & 0,734 & Reliable \\
Purchasing Decision (Y) & 0,836 & Reliable \\
Sources: Data Primer 2018 & & \\
\hline
\end{tabular}

The reliability test results show that all variables have a fairly large Alpha coefficient above 0.6 so that it can be said that all the measuring concepts of each variable from the questionnaire are reliable which means that the questionnaire used in this study is a reliable questionnaire.

\section{Normality Test}

Normality by using the Kolmogorov Smirnov method of analysis. The following table is the result of the Kolmogorov Smirnov method test. 
Effect of E-Word of Mouth through Instagrams to Purchasing Decisions in Twin House Coffee \& Kitchen Restaurant, Cipete, Jakarta Selatan

Table 6 One-Sample Kolmogorov-Smirnov Test

\begin{tabular}{llr}
\hline & & $\begin{array}{r}\text { Unstandardized } \\
\text { Residual }\end{array}$ \\
\hline $\mathrm{N}$ & & 100 \\
Normal Parameters ${ }^{\mathrm{a}, \mathrm{b}}$ & Mean & $0 \mathrm{E}-7$ \\
& Std. Deviation & 2.81893091 \\
Most Extreme & Absolute & .124 \\
Differences & Positive & .124 \\
\multicolumn{2}{c}{ Kolmogorov-Smirnov Z } & -.064 \\
Asymp. Sig. (2-tailed) & Negative & .090 \\
\hline \multicolumn{2}{c}{ a. Test distribution is Normal. } \\
\multicolumn{2}{c}{ b. Calculated from data. } \\
Sources: Primer Data 2018
\end{tabular}

With a basis if the probability (sig) $>0.05$ means the data has been normally distributed. From the results of the SPSS 25.00 test obtained a significance value of 0.090 , the value of $0.090>0.05$, it can be concluded that the data is normally distributed. And can be seen using the P-Plots chart as follows:

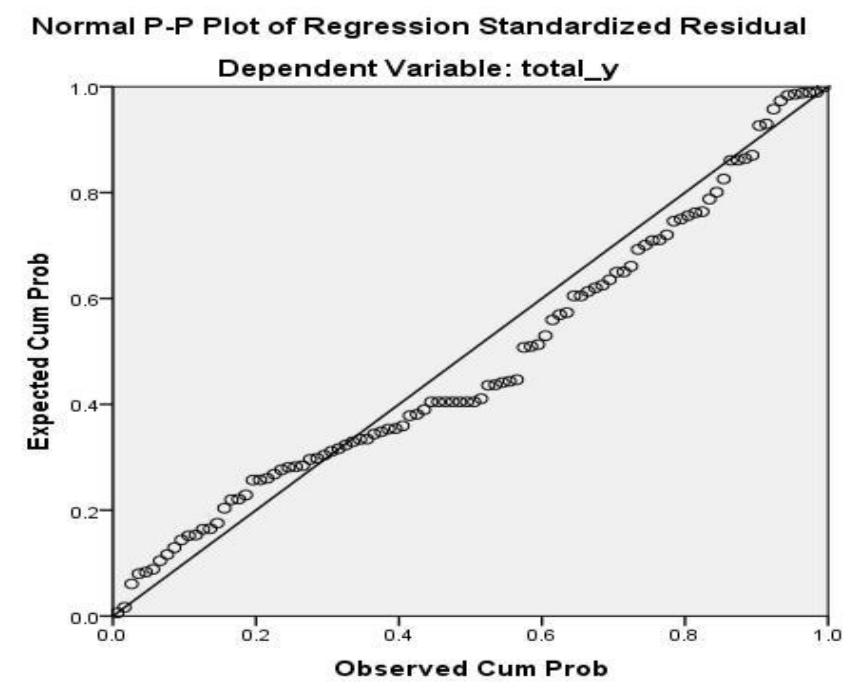

Figure 3 Normality P-Plot

Figure 3 shows that the data spread is near the test line leading to the upper right and no data is located far from the cause of the data. The conclusion is that the data collected in this study is normal and that the appropriate regression model is used to predict purchasing decisions with input from electronic word of mouth (e-WOM) variables through Instagram social media. 


\section{Multicollinearity Test}

Multicollinearity test uses the VIF method. Multicollinearity test results can be seen in table 7 below.

Table 7 Test Results Multicollinearity Coefficient

\begin{tabular}{llrl}
\hline Model & & Collinearity Statistics & \\
\hline & & Tolerance & VIF \\
& (Constant) & & \\
1 & total_x1 & .475 & 2.104 \\
& & & \\
& total_x2 & .379 & 2.636 \\
& total_x3 & .465 & 2.149 \\
\hline
\end{tabular}

a. Dependent Variable: total_y

Sources: Primer Data 2018

From the table above shows that all variables have tolerance values above 0.1 and VIF values are below 10, so it can be concluded that the regression model in this study did not occur multicollinearity.

\section{Heteroscedasticity test}

The following is the result of heteroscedasticity test on the regression model in this study.

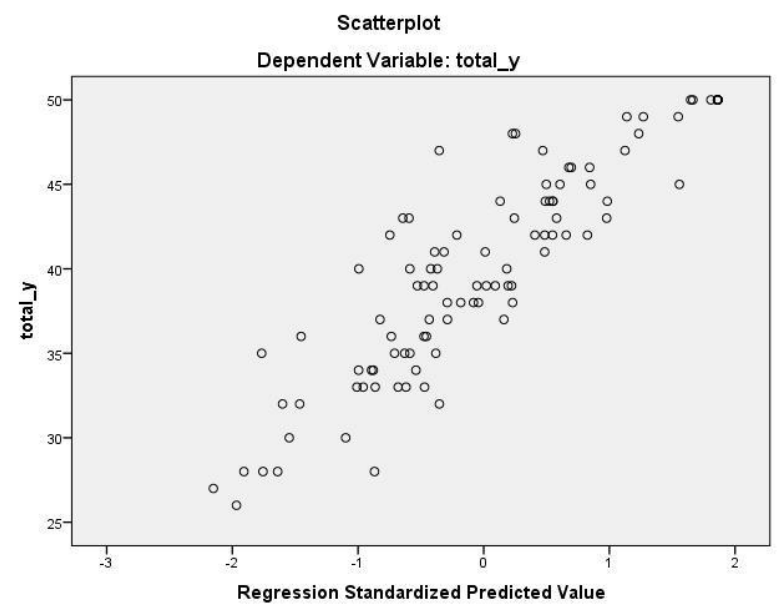

Figure 4 Results Heteroscedasticity Test

Based on figure 4 it can be concluded that heteroscedasticity occurs in the regression model. The heteroscedasticity case that occurs in this study is something that is natural that heteroscedasticity cases often occur when the data used is cross sectional data. This cross sectional data is usually obtained from survey research, data is only collected at one time and no other research will be conducted at different times to compare. 


\section{Regression Analysis Test Results}

In this study using more than one variable as an indicator, namely Electronic word of mouth, namely intensity, and purchasing decisions (Y). testing is done by using the SPSS program. Following are the results of a simple regression test.

Table 8 Results of Regression Analysis

\section{Coefficients $^{\text {a }}$}

\begin{tabular}{|c|c|c|c|c|c|c|}
\hline \multirow[t]{2}{*}{ Model } & & \multicolumn{2}{|c|}{ Unstandardized Coefficients } & $\begin{array}{l}\text { Standardized } \\
\text { Coefficients }\end{array}$ & \multirow[t]{2}{*}{$\mathrm{t}$} & \multirow[t]{2}{*}{ Sig. } \\
\hline & & B & Std. Error & Beta & & \\
\hline \multirow{4}{*}{1} & (Constant) & 2.993 & 1.998 & & 1.498 & .137 \\
\hline & total_x1 & .450 & .135 & .220 & 3.340 & .001 \\
\hline & total_x2 & .815 & .094 & .638 & 8.669 & .000 \\
\hline & total_x3 & .152 & .088 & .115 & 1.734 & .086 \\
\hline
\end{tabular}

a. Dependent Variable: total_y

Sources: Data Primer 2018

$$
\mathrm{Y}=2.993+0.450 \mathrm{X} 1+0.815 \mathrm{X} 2+0.152 \mathrm{X} 3
$$

From the above equation can be explained as follows:

a. The statistic 2,933 . The constant value $(\alpha)$ is equal to 2,933 which means that if the independent variables $\mathrm{X} 1, \mathrm{X} 2$, and $\mathrm{X} 3$ are 0 , the value of the dependent variable is 0.2 .993

b. Regression coefficient $\beta 1$. The regression coefficient value of the intensity variable (X1) is equal to $0.450 \mathrm{~A}$ positive sign on the regression coefficient indicates a unidirectional relationship between $\mathrm{X} 1$ and $\mathrm{Y}$, meaning that if the intensity increases, the purchasing decision will increase by 0.450 .

c. The value of the variable regression coefficient valence of opinion (X2) is equal to 0.815. A positive sign on the regression coefficient indicates a unidirectional relationship between $\mathrm{X} 2$ and $\mathrm{Y}$, meaning that if the valence of opinion increases, the purchasing decision will increase by 0.815 .

d. The regression coefficient value of the content variable (X3) is 0.152. A positive sign on the regression coefficient indicates a unidirectional relationship between $\mathrm{X} 3$ and $\mathrm{Y}$, meaning that if the content increases, the purchasing decision will increase by 0.152 .

\section{Determination Coefficient (R2)}

In this study, researchers tried to find out about the effects of electronic word-of-mouth (eWOM) variables and each dimension on the independent variable on the dependent variable purchasing decision. Electronic word-ofmouth (eWOM) variables consist of three dimensions, namely intensity valence of opinion and content. 
Table 9 Determination Coefficient Test

Model Summary ${ }^{b}$

\begin{tabular}{|c|c|c|c|c|c|}
\hline Model & $\mathrm{R}$ & $\mathrm{R}$ Square & $\begin{array}{c}\text { Adjusted R } \\
\text { Square }\end{array}$ & $\begin{array}{l}\text { Std. Error of } \\
\text { the } \\
\text { Estimate }\end{array}$ & Durbin-Watson \\
\hline & .89 & .803 & .796 & 2.863 & 2.237 \\
\hline
\end{tabular}

a. Predictors: (Constant), total_x3, total_x1, total_x2

b. Dependent Variable: total_y

Sources: Primer Data 2018

In table 9 can be seen the strength of the relationship between variables through the coefficient number of 0.896. Based on the strength of the relationship between variables according to Sugiyono (2016) stated in chapter III, the coefficient number of 0.896 shows the strength of the relationship between variables in this research is very strong. The number of coefficients is positively marked which means that the relationship between variables is unidirectional. Thus, the strength of the relationship between variables is strong towards very strong with positive direction. This shows that the stronger the value of electronic word-of-mouth (e-WOM) through Instagram social media, the stronger the purchasing decision.

From the table above it can be seen, that the adjusted $\mathrm{R}$ square value is 0.796 , which means the independent variable is able to explain the dependent variable of $79.6 \%$. While the remaining $20.4 \%$ is influenced by other variables not included in this study. Researchers assume that this occurs because of possible variables or other factors that are not discussed which might explain the dependent variable more. Researchers assess other factors that can influence purchasing decisions are various other marketing activities from Twin House restaurants, such as Marketing Public Relations (MPR) activities and publicity.

\section{Test $\mathrm{f}$ or Simultaneous Test}

Table 10 Results F Test

ANOVA $^{a}$

\begin{tabular}{llrrrr}
\hline Model & & Sum of Squaresdf & & Mean Square & FSig. \\
\hline \multirow{2}{*}{1} & Regression & 3199.099 & 3 & 1066.366 & $130.129 .000^{\mathrm{b}}$ \\
& Residual & 786.691 & 96 & 8.195 & \\
& Total & 3985.790 & 99 & & \\
\hline
\end{tabular}

a. Dependent Variable: total_y

b. Predictors: (Constant), total_x3, total_x1, total_x2

Sources: Primer Data 2018

Based on table 10 it can be seen that the results of the F test in this study obtained $\mathrm{f}>>$ ftabel that is equal to $130.129>2.46$ with a significance number $(\mathrm{P}$ value) of $0.000<0.05$, it can be concluded that $\mathrm{Ho}$ is rejected and $\mathrm{H} 1$ is accepted. This can be interpreted to mean that the Intensity (X1), Opinion Opinion (X2), and Content (X3) variables have a significant effect jointly on the 
purchasing decision variable $(\mathrm{Y})$ at the restaurant Twin House Coffee \& Kitchen Cipete South Jakarta.

\section{T test or partial test}

The $\mathrm{t}$ test is used to determine whether the multiple linear regression model on the variables $\mathrm{X} 1, \mathrm{X} 2$, and $\mathrm{X} 3$ has an individual significant effect on variable $\mathrm{Y}$.

Table 11 Results t test

Coefficients $^{\text {a }}$

\begin{tabular}{rrrrrrr}
\hline Model & & Unstandardized Coefficients & \multicolumn{2}{c}{$\begin{array}{c}\text { Standardized } \\
\text { Coefficients } \\
\text { Beta }\end{array}$} & t & Sig. \\
& B & Std. Error & Beta & \\
\hline \multirow{2}{*}{$\begin{array}{l}\text { (Constant) } \\
\text { total_x1 }\end{array}$} & 2.993 & 1.998 & & 1.498 & .137 \\
1 & .450 & .135 & .220 & 3.340 & .001 \\
& & & & & & \\
& total_x2 & .815 & .094 & .638 & 8.669 & .000 \\
& total_x3 & .152 & .088 & .115 & 1.734 & .086 \\
\hline
\end{tabular}

a. Dependent Variable: total_y

Sources: Primer Data 2018

Based on table 11 the explanation for each independent variable is as follows:

\section{Intensity Variable (X1)}

The variable $\mathrm{X} 1$ has a positive regression coefficient of 0.450 . The $\mathrm{t}$ count value of the X1 variable was 3.340 and the significance value was 0.001 because the value of tcount $>t$ table $(3.340>1.6688)$ and the significance value of 0.001 $<0.05$, this test shows that Ho is rejected and H1 is accepted, and it can be concluded that the Intensity variable ( X1) has a positive and significant effect on the Purchasing Decision variable (Y).

\section{Valence Opinion Variable (X2)}

The variable $\mathrm{X} 2$ has a positive regression coefficient of 0.152 . The tcount of variable X2 was obtained by 8.669 and the significance value was 0.000 because the value of tcount $>$ ttable $(8.669>1.6688)$ and the significance value of 0.000 $<0.05$, this test showed that Ho was rejected and H1 was accepted, and it could be concluded that the valence variable of opinion ( X2) has a positive and significant effect on the Purchasing Decision variable (Y).

\section{Content Variables (X3)}

The X3 variable has a positive regression coefficient of 0.398 . The calculated value of the X3 variable was 1,734 and the significance value was 0,086 because the value of $t$ count $>t$ table $(1,734>1,6688)$ and the significance value of $0,086>0,05$, this test showed that Ho was accepted and H1 was rejected, and it could be concluded that the content variable ( X3) has no significant positive effect on the Purchasing Decision variable $(\mathrm{Y})$. 


\section{G. Conclusions and Suggestions \\ 1. Conclusion}

Based on the results of the research discussion and interpretations that have been described, by referring to several theories and the results of previous studies, the following conclusions can be drawn:

1. Partially, the dimension of electronic word of mouth is the intensity dimension has a positive and significant effect on purchasing decisions with a significant value of $0.001<0.05$, this test shows that the hypothesis is accepted.

2. The valence variable of opinion has a significant value of $0.000>0.05$, this test shows that $\mathrm{H} 0$ is accepted, and it can be concluded that the valence variable of opinion does not have a positive and significant effect on purchasing decision variables.

3. Furthermore, the content variable has a significant value of $0.086<0.05$, this test shows that $\mathrm{HO}$ is rejected, and it can be concluded that the content variable has a positive effect on purchasing decision variables.

Simultaneously obtained count $>$ ftabel that is equal to $130.129>2.46$ with a significance number ( $\mathrm{P}$ value) of $0.000<0.05$, it can be concluded that $\mathrm{Ho}$ is rejected and $\mathrm{H} 1$ is accepted. This can be interpreted to mean that the Intensity variable (X1), Opinion Opinion (X2), and Content (X3), have a significant effect jointly on the purchase decision variable (Y) at the restaurant Twin House Coffee \& Kitchen Cipete South Jakarta.

\section{Suggestion}

Based on the conclusions above, the researcher put forward some suggestions as follows:

1. Currently consumers can be more critical and easier to express their opinions about the products or services they consume. So to continue to improve the formation of e-WOM through positive Instagram social media, the restaurant must improve the quality of products, prices, and services provided to consumers and must be more active in establishing relationships with their customers.

2. Instagram is the most widely used media for respondents both to do and use e-WOM after and before making a purchase. In addition, the results of the study found that information relating to content variables is most influential for consumers to make purchasing decisions. So, it is better for restaurant and cafe owners to keep abreast of information technology by making official sites on social networking sites, especially Instagram, periodically reviewing to find out which e-WOM is developing, especially those relating to restaurants or cafes that are owned, and providing information that relating to the variety, quality and price of food and beverages sold in a complete manner and attracting the attention of consumers to make purchases in restaurants and cafes. 
3. For academician, the research findings serve as a reference in teaching and learning activities as well as in conducting further research, especially in the field of consumer marketing behavior related to electronic word of mouth through Instagram social media on purchasing decisions.

4. For the next researchers, they are encouraged to investigate deeper and broader about the issue of e-WOM. Add variables that are in line and correlates with the subject area.

\section{REFERENCES}

Alexandrov, A. et al. (2013). The effects of sosial and self motives on the intentions to share positive and negative word of mouth. Journal of the Academy of Marketing Science. Vol. 1. No 5. pp. 531-546.

Atmoko Dwi, Bambang. (2012). Instagram Handbook Tips Fotografi Ponsel.

Goyette, I., Ricard, L., Bergeron, J., and François Marticotte. (2010). e-WOM Scale: Word-of-Mouth Measurement Scale for e-Services Context.Canadian Journal of Administrative Sciences

Goyette, Isabelle. (2012). "Word-of-Mouth Measurement Scale for e-Services Context". Jurnal Word of Mouth. Dalam Dimensi Word of Mouth

Hasan. Ali. (2010). Marketing dari Mulut ke Mulut. Yogyakarta : Media Pressindo Hennig-Thurau., et al. (2004), ElectronicnWord-of-Mouth Via ConsumerOpinion Platforms: What Motive Consumers to Articulate Themselves On the Intenet. Journal of Interactive Marketing. Vol. 18. No 1. pp. 38-52.

Jalilvand, M. R. \& Samiei, N. (2012). The effect of electronic word of mouth on brand image and purchase intention, Marketing Intelegence and Planning, Vol. 30, No. 4, Januari, hlm. 460 -476.

Kotler, Philip. (2009). Marketing Management. Jakarta: Indeks.

Kotler, P. \& Keller, K. L. (2012). Marketing Management. 14th Global Edition. New Jersey: Prentice Hall.

Kotler,P. \& Amstrong, G. (2012). Principles Of Marketing, Global Edition. 14 Edition.Pearson Education.

Natakusumah, Yuan Reza Maulana., Adinoto Nursiana \& Chondro Suryono. (2017). The Impact of Marketing Communication in Attracting Customer (Case Study at Fairmont Hotel Jakarta). Tourism Research Journal, Vol. 1, No. 1: 68 - 80

Peter, P, J, \& Olson, Jerry, C. (2009). Costumer Behavior, Jilid 2, Edisi Kelima (alih bahasa Damos Sihombing). Jakarta. Erlangga.

Setiadi, N. J. (2010). Perilaku Konsumen. Jakarta: Kencana.

Siregar, Syofian. (2014). Metode Penelitian Kuantitatif. Jakarta: Kencana.

Sugiyono (2016). Metode penelitian kuntitatif kualitatif dan R\&D. Alfabeta 
Effect of E-Word of Mouth through Instagrams to Purchasing Decisions in Twin House Coffee \& Kitchen Restaurant, Cipete, Jakarta Selatan

\section{Internet:}

Sumber:http://media.unwto.org/press-release/2015-01-27/over-

11 billiontourists-travelled-abroad-2014diakses pada 5 Februari 2015).

www.zomato.com

Social Media. Report dari The Economist Intelligence unit dari buku berjudul

The

Rise

of

Marketer

(2015). 